University for Business and Technology in Kosovo

UBT Knowledge Center

UBT International Conference

2018 UBT International Conference

Oct 27th, 9:00 AM - 10:30 AM

\title{
Albanian Internal and International Migration
}

\author{
Edmond Dragoti \\ University of Tirana \\ Emanuela Ismaili \\ University of Tirana
}

Follow this and additional works at: https://knowledgecenter.ubt-uni.net/conference

Part of the Psychology Commons

\section{Recommended Citation}

Dragoti, Edmond and Ismaili, Emanuela, "Albanian Internal and International Migration" (2018). UBT International Conference. 411.

https://knowledgecenter.ubt-uni.net/conference/2018/all-events/411

This Event is brought to you for free and open access by the Publication and Journals at UBT Knowledge Center. It has been accepted for inclusion in UBT International Conference by an authorized administrator of UBT Knowledge Center. For more information, please contact knowledge.center@ubt-uni.net. 


\title{
Albanian Internal and International Migration \\ (Desk Research)
}

\author{
Prof. Dr. Edmond Dragoti; Dr. Emanuela Ismaili \\ Department of Social Work and Social Policy, Faculty of Social Sciences, Tirana University
}

\begin{abstract}
Aims of the Study
The overall objective of the study was to depict the characteristics of international and internal migration in Albania and identify the regions most affected by these phenomena. Furthermore, the study sought to identify push and pull factors that led to decisions to migrate. The qualitative approach was used to gather information on the internal and international migration of Albanians.
\end{abstract}

\section{Methodology}

This study was based on a two-fold goal. First, to identify and review relevant literature accumulated on the topic of Albanian migration.

The study included a strong component of literature review that preceded the data collection phase. The desk research phase of the study attempted to identify relevant literature on Albanian migration and developed a database of reports and studies already existing on the phenomenon. Desk research activities consisted of identifying and gathering relevant reports and materials generated by Albanian governmental entities (i.e. Ministry of Labor and Social Affairs), public institutions (e.g. INSTAT) and international agencies (e.g. International Organization for Migration, World Bank, United Nations Development Programme).

\section{Internal Migration in Albania}

During the second half of the 1990s, Albania experienced internal population movements contributing to overall demographic changes in the country. Carletto et al. (2004) define internal mobility based on the movements of the head of household. Their 2004 study concluded that two thirds of household heads were living in their municipality of birth. Whereas $22 \%$ of their sample of heads of household reported moving to a new municipality before 1990, with a smaller percentage (12\%) moving after 1990.

Other research gathered on internal migration, considers those individuals who have changed their prefecture of residency during 1989-2001 (INSTAT, 2004). Long-term internal migration (birth2000) is more difficult to examine because of insufficient information, such as migrants' biographical data.

Studies on internal migration have shown that the majority of the population is young, with $46 \%$ of internal migrants being under 30yo. Only $6 \%$ of internal migrants belong to the retired age group (INSTAT, 2004). When it comes to gender, 54\% of individuals migrating within the country 
are female; although this statistic changes across age (more females migrate at an earlier age, compared to their male counterparts). Some of the reasons to explain this trend pertain to the availability employment possibilities for young females in urban areas and gender-based tradition such as the lack of prospects for property inheritance in rural areas, etc. (INSTAT, 2004). However, gender distributions in internal migration can also be attributed to the fact that females tend to prefer short-term and internal migration, whereas their male counterparts choose long-term, and multiple migrations ranging from internal to international. This recent migration trend makes it harder to capture the true population of males in studies that examine internal migration in Albania.

Family-based migration is another characteristic of internal migration in Albania. According to INSTAT (2004), in 2001 10\% of children between ages 0 and 4 lived in a prefecture different from that in which they lived in 1989. This phenomenon has largely affected children in rural and remote areas of the country.

When examining internal migration in Albania, it is important to examine several factors such as demographics and employment status. Despite the fact that the majority of internal migrants (84\%) is relatively young (15yo-64yo), only $60 \%$ of this population works (INSTAT, 2004). Furthermore, unemployment rates are higher among females $(41 \%)$ than males $(23 \%)$. Women who manage to obtain jobs after migrating to a new area within the country belong to two age subgroups: (15-19yo) and (40-49yo). The former find jobs that do not require formal training and skills, whereas the latter group is comprised of women who have formal and advanced training.

An estimated 900,000 internal migrations occurred in 1991, as the country underwent significant changes while transitioning from a socialist to a democratic system (INSTAT, 2004). According to a household registration conducted in 2001 , the population in rural areas decreased by $13 \%$. Prior to this, the rural population was characterized by increasing levels (20\%). According to INSTAT (2004), internal migration can be examined via two dimensions: space and time. The former pertains to migration occurring within and/or across regions, prefectures, and districts. The latter refers to internal migration occurring from date of birth until 2000, from 1989 to 2001, and 2000 until 2001. When this temporal dimension is taken into account, it can be noted that shortterm (2000-2001) and mid-term forms of internal migration (1989-2001) are interrelated.

According to population and household registration that took place in $2000,5.7 \%$ of the population $(182,600)$ relocated from one region to another between 1989 and 2001. Destinations of migration were central regions (prefectures of Durres and Tirana) and coastal regions (prefectures of Vlore, Fier, and Lezhe). The Northeast and Southeast regions were minimally affected by internal population movements. For example, during the period 1989-2001, internal migration in Central Albania was 44 times higher than in the Northeastern region and 13 times higher than in Southeastern regions (INSTAT, 2004).

Four trends can be identified with inter-regional population movement:

(1) Individuals leaving north and northeastern regions (Kukes and Dibra) and moving to central regions.

(2) Individuals from various parts of the country (Berat, Korce, Elbasan, Gjirokaster, Shkoder) moving toward the center of the country. 
(3) Individuals from secondary coast regions (Fier, Vlore, Lezhe) moving toward the central regions.

(4) Individuals from various central parts of the country migrating to secondary coastal regions. (INSTAT: 2004).

Some internal migration is attributable to poverty and lack of opportunities for economic growth in source areas. For example, $40 \%$ of families in Kukes (Northeastern region) received social welfare, whereas the national average of the welfare index was 12\% (INSTAT, 2000).

Tirana ranks first as a host prefecture followed by Durres, Fier, and Vlora. According to population registration conducted in 2001, $72 \%$ of individuals migrated internally to Tirana and Durres (INSTAT, 2004). The population in these two regions increased by $41 \%$ and $12 \%$, respectively. Furthermore, in $200130 \%$ of the entire population lived in these two regions, as opposed to $23 \%$ in 1989.

This complex and often unregulated and chaotic internal migration has been characterized by low levels of integration between host and newcomer communities, disequilibrium in infrastructure (water, electricity, roads), and education and health care systems. Additionally, more research is needed better to understand the impact of internal migration upon source communities and the influences of internal migration on family subsystems, particularly, spousal, parental, and sibling subsystems.

As opposed to international remittances, little is known about the phenomenon of internal remittances. Findings of research have shown that internal remittances are minimal, (Castaldo \& Reilly, 2007 as cited in Vullnetari, 2007). One interpretation of these findings is that internal migrants are commonly employed in low-paying jobs, leaving little scope for remittance. Alternatively, low levels of remittance may be explained by the fact that Albanian internal migration tends to be more permanent and involves the entire family unit rather than the individual.

\section{Albanian International Migration}

\section{Albanian Migration Before 1945}

Albanian migration pre-1945s is characterized by influxes of population movement within and across the borders. Barjaba et al. (1992) provide a comprehensive analysis of migration based on books and accounts accumulated from scientific scholarly work, as well as journals and personal reflections of travelers who visited the country. Migration prior to 1945 was characterized by economic factors (i.e. individuals migrating as seasonal workers, traders, religious missionaries) and political factors (individuals recruited and those who joined the armed forces in different wars across the Balkan region). Vullnetari (2007) provides a thorough review of early mass migrations of Albanians primarily in Italy (i.e. Sicily and Southern Italy in 1444-1468) and Greece (islands of Eubea, Hydra, and adjacent inland territories) during the $14^{\text {th }}$ and $15^{\text {th }}$ centuries. Some of the factors leading to massive population movements pertain to the Ottoman rule and resistance against its occupation. This resistance resulted in Albanians leaving their country and settling North (Dalmatian coast) and South (Greece). 
Additionally, poverty, low standards of living in rural areas, exploitation of farmers, a heavy taxation system, almost non-existent health care and education systems, wars, and the prolonged Ottoman occupation, all collectively explain the massive migration waves during these years (Vullnetari, 2007). During 1468-1506, an estimated 200,000 Albanians fled the country, representing one quarter of the entire population at that time (Barjaba et al., 2002; Vullnetari, 2007).

Opponents of Ottoman rule and political activists feared persecution and oppression during the second half of the $19^{\text {th }}$ century and the beginning of $20^{\text {th }}$ century. The result was a significant number of migrants fleeing the country and seeking refuge and exile in neighboring countries, as well as in other parts of Western Europe, the United States of America, Argentina, and Australia.

Changing borders, as the result of the treaties of the Balkan Wars (1912-1913) also caused forced migration, resulting in internal displacement of individuals from South to Coastal regions (Durham, 2001) and crossing borders and establishing new settlements in Turkey (the case of Chameria) and North America. Internal population movement occurred within regions and coastal cities attracted people from surrounding areas. Two dimensions characterized internal migration: rural-rural and rural-urban movements (Vullnetari, 2007; Carletto et al., 2004; Tirta, 1999). Tirta (1999) noted that the Southern and Southeastern parts of Albania were most affected by migration, although statistics from the North were scarce and hard to obtain. An estimated 100,000 Albanians emigrated abroad between 1923 and 1925. This figure corresponds to $13 \%$ of the entire population in 1945 (UNDP Albania, 2000.) According to INSTAT (2004), 110,000 Albanians left the country from 1923 to 1939, primarily for reasons of economic and political instability. Furthermore, 19,000 Albanians left the country during 1940-1945 due to their opposition to the rule of the communist party..

In summary, migration of Albanians prior to 1945 was complex and influenced by an interplay of political and economic factors. Massive waves of migration led to a significant shrinkage of the population and established some of the ongoing features of the current migration situation in Albania, such as multiple migration paths and internal population movements. Understanding the early Albanian migration phenomenon can aid our understanding of the antecedents of recent migration and potentially explain and predict the current trajectory of Albanian migration.

\section{Migration during Socialism}

Following World War II, Albania underwent significant political changes and remained a communist and later a socialist country for over four decades. Between 1945 and 1990, international migration was banned and internal population movement was rigidly controlled and planned. Rural-rural migration remained pervasive during the first five years, reflecting agrarian reform of the time and urban population growth emerged only in 1950-1955 (Berxholli, 2000). This increase in urban population was attributed to rural-urban migration and new administrative changes, resulting from industries emerging in the new urban areas (UNDP Albania, 2000).

During the 1960s, there was a plateau of rural-urban demographic shifts, attributed to new reforms undertaken by the authorities in an attempt to retain rural populations by launching minimal 
urbanization policies. The attempts to equilibrate the quality of life in urban and rural areas failed as socio-economic indicators remained worse in rural areas. Nevertheless, the authorities managed to stall rural-urban migration in 1960s and internal movements were highly regulated and occurred only within regions (intra-regional migration). In her comprehensive review of Albanian migration, Vullnetari (2007) noted that the majority of internal migrants were young individuals (19-30yo), male, skilled, and semi-skilled. Censuses taken between 1979 and 1989 reveal a tendency for women to migrate into urban areas, seeking the better education and employment that was only available there.

As mentioned earlier, international movement during the socialist era was banned. However, the borders with Yugoslavia and Greece were somewhat permeable during the early and mid 1950s and 1960s. Those who managed safely to cross the borders were temporarily sent to refugee camps in Greece, Italy, or Yugoslavia and later moved to final destinations in Western Europe (i.e. France, Belgium) or Northern America (U.S.A). As the Albanian authorities monitored borders more closely, crossing became more dangerous and difficult and the incidence more sporadic. Those caught, were accused of betraying their homeland, and received punishment ranging from internal exile, to lifetime imprisonment.

\section{Contemporary Albanian Migration (1990 and Beyond)}

The most recent migratory wave began in 1990 and remains a dynamic and complex process. It should be noted that there is ample literature available on this topic, due to myriad of studies that have been undertaken. Conversely, as mentioned earlier, literature on Albanian migration prior to the 1990s remains scarce and limits full exploration of the phenomenon. Pastore (1992) organizes the major emigration moments in contemporary Albanian emigration into four stages: (1) the stage of protest-migration (1990), (2) the stage of uncontrollable migration (1991-1992), (3) the stage of "sensible migration" (1993-1996) and (4) the stage of flight migration (1997), (as cited in Carletto et al., 2004).

Several studies have been undertaken to examine the pervasiveness of Albanian international migration in the aftermath of the fall of communism in early 90s. It has been estimated (Van der Pol, 1992) that between 1989 and March of 1992 that 220,000 Albanians left the country and this number had increased to 300,000 by the end of 1992 . Another estimate, offered by INSTAT, suggests that 250,000 Albanians lived abroad during this timeframe; this statistic does not include seasonal workers working in Greece (as cited by INSTAT, 2004).

This first wave of migration slowed during stabilization of the political and economic situation (1992-1995), characterized by a decrease in unemployment $(12 \%)$ and inflation rates $(<10 \%)$ and increasing GDP growth rates (from $-7.2 \%$ to $9 \%$ in 1993-1996) (Carletto et al., 2004). However, this economic growth and stability was short-lived and the fall of pyramid "saving" schemes in 1996 paved the way to another migration wave. It should be noted that the "saving" schemes vaguely resembled a credit system, largely sustained by international remittances.\#. Albanians who tried to leave in the aftermath of the fall of the schemes and the subsequent civil unrest were repatriated and Greek and Italian border controls were significantly reinforced. 
Different sources offer varying estimates of the number of Albanian emigrants during these years. Albanian immigrants with a residence (and work) permit in Italy were estimated at 164,000 in 2001 (Bonifazi \& Sabatoni as cited in Carletto et al., 2004). Albanians in Greece were estimated at between 800,000 and 1 million (OECD, 2002), based upon the number of applications for legal residence and those who obtained work permits (858,000 in 2001) (Carletto, et al., 2004).

Similarly, the Return and Readmission Report (IOM, 2006) identifies and describes flows and patterns in Albanian migration, acknowledging that between 1946-1991 international migration was almost non-existent. The first migration flow took place in 1991-1992 when 24,000 Albanians fled to Italy and emigrants represented $9-11 \%$ of the total population by 1995 . The second flow (1997-1998) coincided with the fall of the pyramid schemes and civil unrest, causing another migration wave of Albanians to EU countries (30,000 migrants in Italy; 40,000 in Greece). However, the majority of migrants during this migration wave were repatriated (HLWG, 2003 as cited in IOM, 2006, chapter 1). After this wave of repatriation, Italian and Greek border controls were significantly reinforced. The economy recovered rapidly after the fall of the pyramid schemes and again, this recovery is primarily attributed to the remittances of emigrants living and working abroad. Remittances have played an important role in the recovery of Albania's economy after the fall of the "pyramid schemes" and beyond. According to a report compiled by IOM (2006), the value of remittances is three times as high as foreign net direct investments and nearly twice as much as the developmental aid received by Albania's government.

The third migration wave (1998-1999) occurred during the Kosovo crisis that led to many Kosovars seeking refuge in Albania. An estimated influx of 500,000 Kosovars again changed Albania's demographic landscape although this was a temporary state of disequilibrium. After a brief stay in Albania, many Kosovars sought refuge in other countries in Western Europe, the United States, Canada, and Australia. Albanians also attempted to migrate presenting themselves as Kosovars. Albanian migration during this time is considered "invisible" (IOM, 2006; Vullnetari 2007) because the Albanian authorities were less involved in tracking the effects of this wave of migration.

In subsequent years (2006 and beyond) migration became more difficult for Albanians (enforcement of boundary crossing rules and regulations) and the last flow of international migration pertains to Albanians moving from initial destination countries (i.e. Italy, Greece) to other countries, predominantly the United Kingdom, United States, and Canada. In a recent Migration Profile Report (IOM, 2007) the countries of Greece and Italy are identified as primary destination countries (434,810 migrants in 2003 and 348,813 migrants in 2006, respectively). Other countries that rank high are the United States, United Kingdom, Canada, and Germany.

Additionally, Albania's international migration can be examined by the core push and pull factors that characterize the phenomenon. In his 2004 article, Barjaba identifies unemployment and poverty as the primary push factors influencing decisions and migratory experiences. Other push factors offered by the existing literature include poor living conditions, lack of individual safety and political safety (De Sotto et al., 2002; Hope, 2006). Conversely, hope for a better future and prospects in host countries are key pull factors influencing international migratory experiences. The prospects sought range from education, employment, to overall quality of living for the individual migrant and his or her family (King \& Vullnetari, 2003; Barjaba, 2004). 
Remittances represent a central feature of Albanian international migration. Studies focusing on remittances are based on several sources such as the National Bank of Albania and several formal and informal outlets such as banks, Western Union, family friends, and relatives (IOM, 2006, World Bank, 2005; Vullnetari, 2007, Gedeshi et al., 2003). It is estimated that between 1992 and 2003 remittances ranged from \$ 200 million to \$ 800 million annually (de Zwager et al., 2005), although there is a widespread belief that these figures are underestimates. Estimates that are more accurate are hard to obtain. During the early ' 90 s, remittances were monetary and in-kind, with the latter comprising items such as clothing, furniture, and appliances. However, during the past decade remittances have been mostly monetary. When examining the trend of remittances, an increase can be noted during 1992-1996, a decline in 1997 during the fall of the pyramid schemes and again an increase afterwards, reaching an estimated \$ 1 billion in 2004 and representing 10\% to $20 \%$ of the country's overall GDP (Vullnetari, 2007). Largely, these estimates surpass foreign investments, international aid, revenues generated from export and other similar indices. Overall, remittances have played a crucial role in Albania's economy, in particular preventing and reducing the poverty.

A very interesting finding comes from King et al. (2006) study who revealed gender differences in remittances among senders and recipients. Their findings suggested that male partners of the migrant family send the majority of remittances and the male head of the household in Albania receives them. This finding can be partially explained by the Albanian tradition in which the woman, who gets married, merges her income with her husband's, who ultimately manages the household's income (as cited in Vullnetari, 2007). However, this finding should be interpreted with caution and could be sample specific since participants in this study were Albanians from the North, who migrated in the United Kingdom.

Recipient families and individuals use remittances for a variety of purposes. Some remittances are used to improve the home, renovating, and remodeling. Other remittances are used for traditional and religious rituals, education and covering various expenses (i.e. emergencies, medical treatment) (Balliu, 2007; King \& Vullnetari, 2003). Some studies suggest that there are differences in remittance use between urban and rural households, with the former emphasizing education over house renovation and the latter using remittances to pay off debt and for savings and investment. In her comprehensive report, Vullnetari (2007) describes the trajectory of remittance use through several phases. During the first phase, the money covers core expenses and is used to improve living conditions. In the following phase, money is invested in other ways, such as building a new home close to the parents' home. Research has also shown usage of remittances for investment purposes, opening family-owned businesses such as stores, bars, restaurants, hotels, and mid-size enterprises such as factories, retail, and farming (Kule et al., 2002).

In summary, a review of existing literature on Albanian international migration, leads to several conclusions:

- The phenomenon predominantly affects the working-age young population and is more prevalent among males.

- Migratory experiences are influenced by factors such as unemployment, poverty, lack of individual and collective safety (push factors) as well as economic, educational, and aspirations for a better quality of life (pull factors). 
- International migration can emerge as an individual undertaking and later become a familybased phenomenon, where family members join the individual migrant after an initial period of living abroad.

- Remittances are a key characteristic of Albanian migration, its resources influencing the immediate well-being of family members and indirectly the local economy.

\section{Return Migration}

Over the years, return migration has emerged as another phenomenon within Albanian migration. Return migration can result from changes in various contexts, such as the reasons for migrating (push factors), the individual migrant (i.e. the individual has worked and saved while living abroad and is now thinking of starting a business at home), or the family context (i.e. family reunification is impossible and the individual migrant decides to return home). These factors are often considered to influence voluntary return (Hope, 2006). On the other hand, return experiences can also stem from negative migratory outcomes, such as a failure to obtain regular status in destination countries, forced return, or deportation because of readmission agreements or return practices in the source country (IOM, 2006). According to IOM (2006), prospective returnees may decide to move to big cities upon their return instead of returning to their hometowns. This decision may be explained by the additional opportunities available in larger urban communities. Additionally, a typology of return migrants can be developed based on migrants' experiences during their migratory experiences abroad. For example, returnees can be classified as potential investors, skilled migrants, or without a profession upon return (IOM, 2006). Accordingly, strategies that facilitate return experiences should be differently tailored depending on the needs of the individuals in each category.

Despite the variability of factors leading to voluntary or involuntary forms of migration, there is wide consensus in the literature about the importance of facilitating re-integration experiences. King (2000) points out that reintegration experiences include objective and subjective factors. Objective factors include indices such as the number of returnees who obtain a job after returning home, returnees who access vocational training opportunities, those who start their own business, etc. On the other hand, subjective factors include returnees' perceptions of return, their adjustment experiences in the country of origin, and their outlook on temporary or permanent stay in Albania (IOM, 2006, King, 2000). Return migration in Albania has many of the features mentioned above. It includes both voluntary and involuntary dimensions and experiences of return are considered along a continuum ranging from positive to negative. Regardless of return migratory experience (i.e. voluntary, forced), there is a wide consensus that return migration should be a facilitated process by government and civil society structures. IOM in Albania has played a pivotal role in facilitating the return and reintegration of Albanians over the years, under various initiatives funded by the British Home Office ${ }^{1}$ as well as the European Commission ${ }^{2}$.

Despite emerging research on this phenomenon, return migration remains an understudied area in Albanian migration literature. Undocumented Albanian migrants, particularly those living in Italy

\footnotetext{
${ }^{1}$ Assisted Voluntary Return and Reintegration Programme (VARRP)

${ }^{2}$ Fostering sustainable reintegration in Albania, Kosovo and FYROM, by reinforcing local NGO capacity for service provisions to returnees
} 
and Greece, were more exposed to return than their documented counterparts. Those who were forced to return, attempted to cross the border multiple times and often within short time intervals. In 2004, an estimated 30,000 Albanian migrants returned after failing to achieve proper documentation (legal status) in host countries (de Zwager, 2005).

In an attempt to profile irregular migrants and potential returnees to Albania, IOM (2004) highlights four push factors that lead to international migratory experiences in the first place: (1) general insecurity in country of origin; (2) economic hardship; (3) political reasons; and (4) poor standard of living in country of origin. From a sample of 68 Albanian migrants participating in this study, only $21 \%$ viewed return as a positive step, whereas 16 percent were indifferent to the possibility. The study highlighted three reasons for Albanian migrants to consider the possibility of return: (1) acceptable living standards, (2) secure employment and (3) acceptable level of security. Similar studies have indicated the presence of a relationship between perceptions of success and willingness to return, implying that stronger perceptions of achievement are positively related to willingness to return. In addition to individual factors, societal factors also influence this relationship, such as meanings ascribed to the return phenomenon in host and source societies. When return is viewed as a personal failure, the individual immigrant is less prone to consider return as a possibility. Therefore, an emphasis on mass information campaigns and reintegration assistance programs to foster positive feelings and expectations among potential returnees, would buffer the negative effects of stereotypes of return migration.

In summary, literature already existing on Albania's return migration phenomenon indicates that return migration can result from

(a) the voluntary decision of the individual;

(b) the individual decision if coupled with an assisted voluntary program; or

(c) the individual if forced to return (IOM, 2003).

Furthermore, return decisions can stem from various reasons, such as failure to obtain regular status in destination countries, personal and family reasons (i.e. health, feeling homesick, etc.). Secondly, upon return, migrants can still face the obstacles they experienced prior to migration abroad, such as unemployment and economic difficulties. These factors can influence decisions about temporary or permanent return, making return migration a time-sensitive phenomenon in Albania.

Thirdly, not all return migrants receive assistance from governmental and non-governmental programs. When assistance is available, it facilitates reintegration experiences in both subjective (i.e. adjustment) and objective levels (i.e. attending a workshop, professional training opportunities, obtaining loans to start a business etc.).

\section{Conclusions Emerging from Desk Research}

When attempting to understand the demographic dimensions of Albania's internal migration, several conclusions can be reached. The majority of the population is young and this has implications on the labor markets, which are increased in host communities and decreased in communities of origin. The male/female ratio in internal migration is more proportionate that the male/female ratio in international migration (1:1 versus 3:1, respectively). Additionally, coastal 
and central prefectures are most usually destination regions, whereas north and northeastern prefectures are often source regions.

As with internal migration, international migrants are also characterized as young, with more males migrating than females. Furthermore, international migrants tend to work in sectors such as construction, manufacturing, and services, with more women employed in domestic settings. Additionally, international migration is often a multistep process with neighboring countries (Greece, Italy) serving as primary countries of destination and later used as trampolines to migrate to other destinations. The most commonly identified destination countries are Greece, Italy, Austria, Canada, France, Germany, United Kingdom, and the United States.

Return migration has emerged as a result of multiple factors, such as difficulties in obtaining proper documentation in destination countries, difficulties in obtaining family reunifications abroad and political and economic stability in Albania. As a result, voluntary return has become more prevalent recently and the prospects for temporary return are often predictors of permanent return to Albania.

In summary, Albania's international and internal migrations remain complex phenomena to describe and quantify. Irregular migration adds more complexity to understanding international migration and estimates fluctuate across sources of information. As a result, international and internal migration has collectively changed the demographic landscape of Albania. The consequences go beyond the total population estimate and affect other domains, such as the overall economic and infrastructure changes in the country, the labor market, and gender- and age- ratios.

This section of the report attempted to uncover some of the characteristics of contemporary Albanian migration, the paths and trajectories and the rationale behind them, whereas the estimates provided are simply numbers that describe but do not define the phenomenon.

\section{REFERENCA}

Barjaba, K. (2004). Shqipëria: Duke parë përtej kufijve (Albania: Looking Beyond Borders). Marrë nga Burimi Informativ për Migracionin në: http://www.migrationinformation.org.

Bërxholi, A. (2000). Regjistrimet e përgjithshme të popullsisë në Shqipëri: Vështrim Historik (Censuses in Albania: A Historical Perspective). Tiranë: Akademia e Shkencave, Qendra e Studimeve Gjeografike.

Carletto, G., Davis, B., Stampini, M., \& Zezza, A. (2004). Lëvizja e brendshme dhe migracioni ndërkombëtar në Shqipëri (Internal Mobility and International Migration in Albania). Romë: FAO, ESA, Studim 04-13.

De Soto, H., Gordon, P., Gedeshi, I., \& Sinoimeri, Z. (2002). Varfëria në Shqipëri: Një vlerësim cilësor (Poverty in Albania:A Qualitative Assessment). Washington DC: Dokument teknik i Bankës Botërore 520.

International Organization for Migration (IOM) (2005). Konkurrenca për dërgesat në para të emigrantëve (Competing for Remmittances). Tiranë: IOM Tirana.

Gedeshi, I., Mara, H., \& Preni, X. (2003). Nxitja e zhvillimit social-ekonomik në lidhje me rritjen e rolit të dërgesave në para të emigrantëve (The Encouragement of Social-Economic

Development in Relation to Growth of the Role of the Remittances). Tiranë: Qendra për Studime Ekonomike dhe Sociale.

Danaj, S. (2006). Një analizë e aktivitetit të shoqatës Shpresë për të Ardhmen për periudhën Prill-Qershor 2006 (An Analysis of the Activity of Hope for the Future Association for the Period April 1999-June 2006). Shoqata Shpresë për të Ardhmen: Tiranë, Shqipëri.

Qeveria e Shqipërisë (2005). Strategjia Kombëtare për Migracionin dhe Plani Kombëtar $i$ Veprimit për Migracionin: Rruga drejt menaxhimit të migracionit (National Strategy on Migration and National Action Plan on Migration: The Road Towards Migration Management). Tiranë: Shqipëri. 
Organizata Ndërkombëtare për Migracionin (2007). Republika e Shqipërisë: Profili i migracionit. (The Republic of Albania: Migration Profile). Ministria e Brendshme e Republikës së Sllovenisë: Ljubjana.

Organizata Ndërkombëtare për Migracionin (2006a). Kthimi dhe ripranimi: Rasti i Shqipërisë (Return and Readmission: The Case of Albania). IOM, Tiranë: Shqipëri.

Organizata Ndërkombëtare për Migracionin (2006b). Institucionalizimi i asistencës për migrantët e kthyer në Shqipëri përmes zyrave lokale të punësimit dhe OJQ-ve lokale (Institutionalizing Assistance to Returned Migrants in Albania through Local Employment Offices and Local NGOs). IOM, Tiranë: Shqipëri.

International Organization for Migration (IOM) (2004). Profili i migrantëve të parregullt dhe analiza e nevojave për riintegrim të të kthyerve të mundshëm nga Kosova (Serbia dhe Mali i Zi) Shqipëria dhe IRJ e Maqedonisë $n \ddot{e}$ Belgjikë, Itali, Mbretërinë e Bashkuar dhe Gjermani (Profiling of irregular migrants and analysis of reintegration needs of potential returnees from Kosovo (Serbia and Montenegro), Albania, and FYROM in Belgium, Italy, the United Kingdom, and Germany). Raport përfundimtar i studimit për Komisionin Evropian.

Organizata Ndërkombëtare për Migracionin (2004). E drejta migratore ndërkombëtare: Fjalor i migracionit (International Migration Law: Glossary on Migration). IOM, Gjenevë: Zvicër.

Organizata Ndërkombëtare për Migracionin (2003). Identifikimi i qasjeve të qëndrueshme ndaj kthimit vullnetar dhe riintegrimit të azilkërkuesve dhe personave me status të mbrojtjes së përkohëshme: Shqipëri, Rumani dhe Rusi (Identification of Sustainable Approaches to Voluntary Return and Reintegration of Asylum Seekers and Persons with Temporary Protection Status: Albania, Romania, and Russia). Përgatitur nga Hulst, M., Laczko, F., \& Barthel, J. Raport përfundimtar i projektit për Komisionin Evropian. Divizioni i Studimeve dhe Publikimeve në IOM.

INSTAT (2004a). Migracioni në Shqipëri në vitin 2001. Tiranë: Instituti I Statistikës.

Fondacioni Evropian për Trajnimin (ETF) (2007). Kontributi i zhvillimit të burimeve njerëzore në politikën e migracionit Shqipëri (The Contribution of Human Resources Development to Migration Policy in Albania).

King. R. \& Vullnetari, J. (2003). Migracioni dhe zhvillimi në Shqipëri (Migration and Development in Albania. WP C5), Qendra e Studimeve mbi Zhvillimin dhe Migracionin, Globalizimin dhe Varfërinë, Universiteti i Saseksit, marrë nga: http://www.migrationdrc.org/publications/working_papers/WP-C5.pdf.

Pastore, F. (1998). Konfliktet dhe migracioni: Një rast studimor për Shqipërinë (Conflicts and Migration: A Case Study on Albania). Përshkrim i shkruar për Rrjetin e Parandalimit të Konfliktit të Komisionit Evropian.

Piperno, F. (2002). Nga Shqipëria në Itali. Struktura dhe elementet themelorë të një sistemi migrator të dy vendeve (From Albania to Italy. Formation and basic features of a binational migration system). Dokument shpjegues për misionin CEME-CeSPI në Itali dhe Shqipëri.

Programi për Zhvillim i Kombeve të Bashkuara (UNDP) Shqipëri (2000). Raporti i zhvillimit njerëzor për Shqipërinë 2000 (Albanian Human Development Report 2000). Tiranë: UNDP Shqipëri.

Kombet e Bashkuara, Departamenti i Ekonomisë dhe Çështjeve Sociale, Divizioni i Statistikave (1998). Rekomandime për statistikat e migracionit ndërkombëtar (Recommendations on Statistics of International Migration). Seria e dokumentave statistikore, M, Nr 58, Rev 1. Kombet e bashkuara: Nju Jork.

Tirta, M. (1999). Migrime të shqiptarëve, të brendshme dhe jashtë atdheut (vitet '40 të shek. XIX - vitet '40 të shek. XX). Etnografia Shqiptare, 18.

Vullnetari, J. (2007). Migracioni shqiptar dhe Zhvillimi:Rishikim i kohëve të sotme (Albanian Migration and Development: State of the Art Review). Dokument i IMISCOE. 